\title{
Study on Debt Structure, Ownership Structure and Solvency: Based on Automobile Listed Companies
}

\author{
Jie Liu ${ }^{1, a^{*}}$ and Mingran Deng ${ }^{2, b}$ \\ ${ }^{1}$ School of Management, Wuhan University of Technology, Wuhan, P. R. China, \\ ${ }^{2}$ School of Management, Wuhan University of Technology, Wuhan, P. R. China, \\ a1332996244@qq.com, bdmr@whut.edu.cn
}

Keywords: Capital structure; Solvency; Automobile industry; Factor analysis; Correlation analysis

\begin{abstract}
With the development of the capital market and the more vigorous market competitions, the debt management is generally adopted by many enterprises. Debt management not only solves the shortage of funds for enterprises, but also has many risks such as increases the pressure on corporate debt and even leads to the bankruptcy liquidation. Based on the above analysis, this paper concentrated on the study of listed company's debt structure, ownership structure, solvency and their relationship. Firstly, it builds the evaluation index system of debt structure, ownership structure and solvency based on the theoretical analysis; Secondly, it selects China's auto industry listing Corporation as empirical sample and gets the formula of structure debt structure, ownership structure and solvency through factor analysis and principal component analysis; Thirdly, it studies the relationship among debt structure, ownership structure and solvency by using correlation analysis performed in SPSS software; Lastly, it arrives at the conclusion of this study and gives advices on the finance mode of China's automobile industry and the improvement of their solvency.
\end{abstract}

\section{Introduction}

At present, China is actively developing convertible bonds, perpetual notes and debt instruments with proprietary rights. With the increasingly capital market, China's listing Corporation has more financing channels. Some listing Corporations prefers the issuance of bonds, loans and commercial credit for that debt management could get financed rapidly. Some are more inclined to non-debt management like stocks, retained profits. In modern enterprise management, fast financing enable enterprises to seize the opportunities in fierce competition. And debt management has become a common financing model, but excessive debt will not only increase the enterprise debt burden and it's more likely to make enterprise capital chain rupture or even leads to bankruptcy [1]. So what is the effect of debt management to listing Corporation's solvency? Does ownership structure have any effect on solvency except debt structure? In order to solve the above problems, this paper mainly uses factor analysis and correlation analysis to do empirical studies on debt structure, ownership structure and the solvency of listing Corporations. In addition, with the increased status of China's automobile industry in the global auto market, the automobile enterprises are facing huge financial demand and great competition pressure. Therefore, this article chooses the automobile listing corporations as the research object and aim to give them useful suggestions on choosing better financing model and improving the solvency.

\section{Literature Review}

In the measure of solvency, scholars hold consistent opinions. Gan Sheng Dao (2008) pointed out that cash ratio is more suitable than profit ratio because debt will eventually be repaid in cash [2]. Gao Dagang (2010) thought that interest coverage ratio, cash debt coverage ratio and asset-liability ratio could measure enterprises' long-term debt solvency [3]. This paper finally selects current ratio, quick ratio and cash flow ratio as a measure of short-term solvency indicators and meanwhile interest coverage ratio and cash flow interest coverage ratio as a measure of long-term solvency indicators. In the measure of debt structure, Qi Yongjun (2007) chose debt sources and debt 
maturity to describe the debt structure. [4]. the author selects assets-liability ratio, debt-to-long capital ratio and Long term loan to total assets ratio as the measuring indicators of debt structure. In the measure of ownership structure, Huang Hui (2006) selects top five shareholders as indexes of ownership structure [5]. Zhao Dongqing (2008) studied on China's real estate corporation. Results show state-owned ratio and asset-liability ratio is correlated [6]. In this paper, the ownership structure includes ownership concentration and property. Then ownership concentration is measured by the top five shareholders proportion and state ownership ratio represents ownership property.

Recently, there are many academic researches on debt structure and solvency, but their conclusions vary from each other and even have contradiction for different industries. Most people think they are related. Harris (1990) found that the rate of assets and liabilities was negatively related to solvency [7]. Lu Sha (2012) took company size, profitability and solvency as major factors which influence the capital structure. She got that the solvency and asset liability ratio has a significant negative correlation [8]. Yang Nan (2014) selected small and medium high-tech enterprises in China's gem as the sample and found that solvency and capital structure had significantly positive correlation based on panel data analysis [9]. Some people found that debt structure and solvency are maybe not related. Titman, Wessles (1988) thought that debt level had nothing to do with enterprise solvency [10]. Yuan Weiqiu (2009) pointed out that company's debt structure is related to short-time solvency while not related to long-term solvency [11].

In summary, most scholars focus on the relationship between debt structure and solvency while neglect the relationship between debt and equity structure. Therefore, this paper studies the relationship among debt structure, equity structure and solvency. And selects the automobile industry listed companies as the research object in order to make up the gap in this industry.

\section{Research Design}

MM capital structure theory thinks debt financing of enterprises can reduce the weighted average cost of capital with the tax effect of debt. But once the debt exceeds the acceptable level, the weighted average cost of capital is not decreased with the increase of debt. Large amount of debts are difficult to repay and even lead to bankruptcy. As referred on the above studies, transportation and warehousing industry listing Corporations' solvency is significantly negatively related to the asset-liabilities rate. And the high tech SMEs' solvency is positively related to capital structure. Based on these found, this paper put forward the following assumptions:

Hypothesis One: the solvency of the enterprise is related to the debt structure.

The theory of capital structure influence factors think profitability, solvency and operation ability all could have impact on capital structure. And capital structure includes both debt structure and ownership structure. So except the impact of debt structure on solvency, ownership structure should also be associated with solvency. What's more, researchers have found that ownership concentration and asset liability ratio are positively related. So this paper puts forward the following assumptions:

Hypothesis Two: the solvency of the enterprise and the ownership structure is related.

\section{Variable Definition}

The solvency is dependent variable and it refers to the ability of the enterprise to repay the debt. According to the repayment period of the debt, the solvency can be divided into short-term solvency, long-term solvency and total solvency. Through principal component analysis, we get three principal components as explanatory variables, namely debt structure, ownership concentration and ownership nature. The variables selected in this paper are as follows: 
Table 1 variable description

\begin{tabular}{c|c|c}
\hline Level-one variables & Level-two variables & Variables description \\
\hline \multirow{2}{*}{$\begin{array}{c}\text { Short term solvency } \\
\text { (SLS) }\end{array}$} & Current ratio(Y1) & Current assets / current liabilities \\
\cline { 2 - 3 } & Cash ratio(Y2) & Cash / current liabilities \\
\cline { 2 - 3 } & Cash flow ratio(Y3) & Operating cash flow / current liabilities \\
\hline $\begin{array}{c}\text { Long term solvency } \\
\text { (SLL) }\end{array}$ & Interest coverage ratio (Y4) & EBIT/interest \\
\cline { 2 - 3 } Debt structure & Cash flow interest coverage ratio (Y5) & Operating cash flow / interest \\
(DT) & Asset liability ratio (X1) & Total liabilities / total assets \\
\cline { 2 - 3 } & Long term capital debt ratio (X2) & Non-current liabilities / (non-current \\
\cline { 2 - 3 } & Long term loan to total assets ratio & Long term loan / total assets \\
\hline Equity concentration (OC) & The top five largest shareholder (X4) & Total shareholding ratio of the top five \\
\hline Equity nature (OP) & State shareholder(X5) & state owned ratio \\
\hline
\end{tabular}

\section{Analysis Results}

The author selects the automotive industry listed companies in China as the research object, and collects financial indicators from 2007 to 2015 as the basic data. The KMO of indicators' factor analysis is 0.567 , indicating that these indicators are suitable for factor analysis. At the same time, the significance level of Bartlett's Sphericity Test is 0.000 , less than $1 \%$, indicating that correlation coefficient matrix is not the unit matrix and the variables are correlated. In addition, Table 2 shows the first factor has high load in current ratio, cash ratio and cash flow ratio, which reflects the enterprise short-term solvency and is expressed as SLS. Then the second factor has high load in interest coverage ratio and cash flow interest coverage ratio, which reflects the enterprise's long-term solvency and is expressed as SLL.

Table 2 factor score coefficient matrix

\begin{tabular}{c|c|c}
\hline \multirow{2}{*}{} & \multicolumn{2}{|c}{ Components } \\
\cline { 2 - 3 } & 1 & 2 \\
\hline Y1 Current Ratio & 0.416 & -0.029 \\
\hline Y2 Cash Ratio & 0.417 & -0.034 \\
\hline Y3 Cash Flow Ratio & 0.309 & 0.022 \\
\hline Y4 Interest Coverage Ratio & -0.023 & 0.514 \\
\hline Y5 Cash Flow Interest Coverage Ratio & -0.009 & 0.512 \\
\hline
\end{tabular}

According to Table 2, we can get the linear expression of the short-term solvency and long-term solvency, as follows:

$\mathrm{SLS}_{\mathrm{it}}=0.416 \mathrm{Y} 1_{\mathrm{it}}+0.417 \mathrm{Y} 2_{\mathrm{it}}+0.309 \mathrm{Y} 3_{\mathrm{it}}-0.023 \mathrm{Y} 4_{\mathrm{it}}-0.009 \mathrm{Y} 5_{\mathrm{it}}$

$\mathrm{SLL}_{\mathrm{it}}=-0.029 \mathrm{Y} 1_{\mathrm{it}}-0.034 \mathrm{Y} 2_{\mathrm{it}}+0.022 \mathrm{Y} 3_{\mathrm{it}}+0.514 \mathrm{Y} 4_{\mathrm{it}}+0.512 \mathrm{Y} 5_{\mathrm{it}}$

The factor variance contribution shows that the weight of the first main factor is $46.461 \%$, the weight of the second principal factor is $36.937 \%$, and the weighted total score is defined as the comprehensive Solvency Index, which is expressed as SL.

$\mathrm{SL}_{\mathrm{it}}=46.461 \% * \mathrm{~F} 1_{\mathrm{it}}+36.937 \% * \mathrm{~F} 2_{\mathrm{it}}$

With the same method, the study analyses indicators of debt structure and ownership structure. Asset-liability ratio, long-term capital debt ratio and long-term loans to total assets ratio belong to a main factor, which is expressed as DT, describing the proportion of corporate assets and liabilities. Proportions of top five shareholders represent a main factor, which describes the enterprise equity concentration and is expressed as OC. the last main factor is defined as state-owned shareholders to reflect the nature of equity. And the formulas of debt structure, ownership concentration and nature of ownership are as shown below:

$\mathrm{DT}_{\mathrm{it}}=0.315 \mathrm{X} 1_{\mathrm{it}}+0.451 \mathrm{X} 2_{\mathrm{it}}+0.417 \mathrm{X} 3_{\mathrm{it}}+0.078 \mathrm{X} 4_{\mathrm{it}}-0.012 \mathrm{X} 5_{\mathrm{it}}$
$\mathrm{OC}_{\mathrm{it}}=-0.238 \mathrm{X} 1_{\mathrm{it}}+0.100 \mathrm{X} 2_{\mathrm{it}}+0.153 \mathrm{X} 3_{\mathrm{it}}+0.941 \mathrm{X} 4_{\mathrm{it}}+0.004 \mathrm{X} 5_{\mathrm{it}}$
$\mathrm{OP}_{\mathrm{it}}=0.151 \mathrm{X} 1_{\mathrm{it}}-0.020 \mathrm{X} 2_{\mathrm{it}}-0.110 \mathrm{X} 3_{\mathrm{it}}+0.014 \mathrm{X} 4_{\mathrm{it}}+0.976 \mathrm{X} 5_{\mathrm{it}}$ 
Among them, the letter i represents each listing Corporation, $i=1,2 \ldots 91 ; \mathrm{t}$ represents each year, $\mathrm{t}=2007,2006 \ldots 2015$.

(2) Correlation Analysis

Two tailed test results tell that short-term solvency has significant negative correlation with debt structure and equity nature, and also has significant positive correlation with equity concentration. Moreover, long-term solvency and total solvency all have positive correlation with equity concentration. The hypothesis one and hypothesis two have been verified.

What's more, different research objects do have different relationships among these variables. This paper takes the asset liability ratio as control variable to classify the objects. The average asset liability ratio of the total sample is $48.08 \%$, and then the ratio is set to "very low", "low", "medium", "high" and "very high" five grades. "Very low" asset liability ratio is less than 20\%; "low" asset liability ratio is greater than $20 \%$ and less than $40 \%$; "medium" asset liability ratio is greater than $40 \%$ and less than 60\%; "high" asset liability ratio is greater than $60 \%$ and less than $80 \%$; "very high" asset liability ratio is more than $80 \%$. In accordance with the different level of assets and liabilities, the relationship among debt structure, ownership structure and solvency are as shown in the following table:

Table 3 correlation coefficient

\begin{tabular}{c|c|c|c|c|c}
\hline Asset-liability level & Very low & Low & Medium & High & Very high \\
\hline Short-term solvency \& debt structure & -0.128 & -0.046 & $0.236^{* *}$ & -0.046 & -0.323 \\
\hline Short-term solvency \& equity & -0.052 & $0.307^{* *}$ & $0.220^{* *}$ & $0.201^{* *}$ & -0.201 \\
\hline Short-term solvency \& equity nature & -0.052 & -0.078 & -0.080 & -0.144 & -0.393 \\
\hline Long-term solvency \& debt structure & 0.054 & 0.079 & 0.050 & -0.033 & 0.009 \\
\hline Long-term solvency \& equity & 0.019 & 0.165 & 0.057 & 0.015 & -0.140 \\
\hline Long-term solvency \& equity nature & -0.002 & 0.009 & -0.027 & -0.060 & 0.055 \\
\hline Total solvency \& debt structure & 0.052 & 0.079 & 0.050 & -0.034 & 0.005 \\
\hline Total solvency \& equity concentration & 0.019 & 0.165 & 0.057 & 0.017 & -0.141 \\
\hline Total solvency \& equity nature & -0.002 & 0.009 & -0.027 & -0.062 & 0.050 \\
\hline
\end{tabular}

From Table 3, when enterprise asset-liability ratio is "very low" or "very high", short-term solvency, long-term solvency, total solvency, debt structure and ownership structure have no significant correlation; when enterprise asset-liability ratio is "low" or "high", short-term has significant positive correlation with equity concentration, indicating that enterprises have more shareholding ratio of the top five shareholders, they will have more repay ability to borrow short-term debts. But enterprises with "low" or "high" debt level have no other correlations besides the short-term solvency and equity concentration; when enterprise asset-liability ratio is "medium", short-term solvency has significant positive correlation with both debt structure and equity concentration, indicating that enterprises have more debts or shareholding ratio of the top five shareholders, they could repay short-term solvency more easily.

\section{Summary}

Based on the empirical analysis about debt structure, ownership structure and solvency, we get the following conclusions:

(1) The short-term solvency, debt structure and equity structure of automobile industry listing Corporation have the significant correlation for enterprises could easily and quickly arrange the current assets and liabilities.

(2) Total solvency of listing Corporation in automotive industry mainly depends on the long-term solvency. Both of them have relationship with equity concentration because the absolute controlling shareholder decides the long-term distribution of enterprises' sources.

(3)The whole correlation results are different from the classified correlation results in some aspects, e.g. the short-term solvency has whole significant negative correlation with debt structure 
but has positive correlation with debt structure to the "medium" enterprises. And the long term solvency and total solvency do have relationship with equity concentration as a whole study but have no relationship in the classified researches. Thus automotive industry listed companies should firstly determine their debt level in the industry from the industry analysis. And then find out the relevance results in this study. Finally, take suitable measures to change asset-liabilities ratio, equity concentration and etc. to optimize their own financing mode, so as to improve the solvency of enterprises.

\section{References}

[1] Wang Yuying, Analysis of issues related to debt management, J. Journal of Finance and Accounting. 2(2008) 16-17.

[2] Gan Shengdao, Construction of index system for enterprise payment ability, J. Financial and Accounting Communication. 4(2008) 61-62.

[3] Gao Dagang, Solvency general index, J. Economic Question. 8(2010) 111-118.

[4] Qi Yongjun, Influence of debt structure on the market competitiveness of enterprises, J. Financial and Accounting Communication. 10(2007) 96-99.

[5] Huang Hui, Wang Zhihua, Empirical analysis on the differences of capital structure and influencing factors, J. Financial Theory and Practice. 27(2006) 67-71.

[6] Zhao Dongqing, Zhu Wuxiang, Wang Zheng, Macro control and real estate listing corporations' capital structure adjustment, J. Financial Research. 10(2008) 78-92.

[7] Harris M. Raviv A. Capital structure and the information role of debt, J. Journal Of Finance. 45(1990) $321-349$.

[8] Lu Sha, The influence factors' analysis of listing corporation capital structure: the empirical data from china's real estate industry (2012)

[9] Yang Lan, The impact factor analysis of capital structure on high technology enterprise, J. Journal of Jinan University. 3(2014) 136-143.

[10] Titman S. Wessels R, The determinant of capital structure choice, J. Journal of Finance. 1(1988): 43- 19.

[11] Yuan Weiqiu, Debt maturity structure, debt paying ability and financing structure flexibility: empirical evidence from listing corporation, J. Journal of Yunnan University. 3(2009) 60-67. 